\title{
Coupled Inductor Based Single Phase CUK Rectifier Module for Active Power Factor Correction
}

\author{
Jidhun K Murali and Arun Rajendran
}

\begin{abstract}
Nowadays power supplies with active Power Factor Correction (PFC) techniques are becoming necessary for many types of electronic equipment to meet harmonic regulations and standards, such as the IEC 61000-3-2. Power Factor Correction shapes the input current of power supplies in such a way to maximize the real power available from the mains. This paper analyses the function of high quality CUK rectifier module as a power factor correcting device in continuous conduction mode. The converter is designed by utilizing the idea of integrated magnetics. The control scheme consists of an inductor current calculator and an output voltage loop. Both Experimental and Simulation results are presented.
\end{abstract}

Keywords--- Power Factor Correction(PFC), Coupled Inductor, Current THD, Single Phase Converter

\begin{tabular}{ll}
\hline & \multicolumn{1}{c}{ NOMENCLATURE } \\
$\mathrm{C}_{\mathrm{a}}, \mathrm{C}_{\mathrm{b}}$ & Intermediate capacitor. \\
$\mathrm{C}_{0}$ & Output capacitor. \\
$\mathrm{CCM}$ & Continuous Conduction Mode \\
$\mathrm{d}$ & Duty-cycle. \\
$\mathrm{D}$ & Diode. \\
$\mathrm{L}_{1}$ & Input side inductor. \\
$\mathrm{L}_{2}$ & Output side inductor. \\
$\mathrm{M}, \mathrm{nTr}$ & The voltage relation in CCM; the turns \\
& ratio between primary and secondary. \\
$\mathrm{T}_{\mathrm{sw}}$ & Switching period. \\
$\mathrm{I}_{\mathrm{L} 1}$ & Inductor current. \\
$\mathrm{I}_{\mathrm{vr}}$ & Correcting signal from PI controller. \\
$\mathrm{I}_{\mathrm{Lrefi}}$ & Reference value for the peak value of \\
& input inductor current. \\
$\mathrm{I}_{\mathrm{m}}$ & Peak value of input inductor current. \\
$\mathrm{K}_{\mathrm{a}}$ & Conduction parameter. \\
$\mathrm{V}_{\mathrm{g}}$ & Rectified input voltage. \\
$\mathrm{V}_{0}$ & DC output voltage. \\
$\mathrm{I}_{\mathrm{load}}, \mathrm{I}_{0}$ & Load current.
\end{tabular}

Jidhun K Murali, Student, Electrical and Electronics, Amrita University, Kollam, India, E-mail: jidhunkm@gmail.com

Arun Rajendran, Assistant Professor, Electrical and Electronics, Amrita University, Kollam, India, E-mail: arunrajedren@gmail.com

\section{INTRODUCTION}

$M$ OST of the electronic or electrical apparatus often requires dc power at multiple voltage levels. In the case of AC-DC-DC switching power supply, a full wave rectifier with a parallel capacitor are often used to obtain the initial DC voltage for the subsequent dc to dc converter. As the rectifier is non-linear and the capacitor is an energy-storage component, the combination of them will make the input current distort greatly. The pulsating input current contains a large amount of harmonic components. This will cause the reduction of input power factor as well as, a lot of current harmonic emission will create the line voltage distort and damages to adjacent equipments. In order to lessen the pollution caused by input harmonic current of ac to dc converter and improve the input power factor, measures should be taken to reduce the harmonic components of the input current [14].

So the dc to dc conversion is an important element in the power electronic field. Now a day in industries, commercial, residential, aerospace, electronic equipment, telecommunication \& computer systems the high class rectifiers have a great value [1]. These converters have to meet with international standards for electronic compatibility \& accurate regulation, therefore most of the converter uses an active Power Factor Correction circuit which reduces the input harmonic distortions [5].

The majority of the high quality rectifier uses boost converter for Power Factor Correction. The PFC is achieved by controlling the switching action of the converter. This will create the input current to follow a reference sinusoidal current and to attain the input power factor close to unity. But boost converter has got some limitation. Basic limitations of boost converter can overcome by using CUK converter. CUK converter can be attractive for PFC applications because it offer easy implementation of transformer isolation[3][11], inherent inrush current limitation during start-up and overload conditions, and ability to generate arbitrary output voltages[9][10]. Integration of magnetic components is also possible in the case of CUK converters, with zero current ripples in both input and output inductors [2]. The further benefits can be achieved by the magnetic integration such as lower operating frequency, high power density, high efficiency, low cost, low noise and EMI, and small-size filtering component at the input and output side. So a single phase CUK rectifier module is proposed [1]. 
Figure 1 shows a single phase CUK rectifier module with input and output inductor coupled. It consist of two sections an input and an output section. Input section is similar to a boost converter, while the output section resembles that of a buck stage. It produces negative output voltage from a positive input voltage. Here the Coupled Inductors reduces input and output current ripples and the transformer provide proper isolation

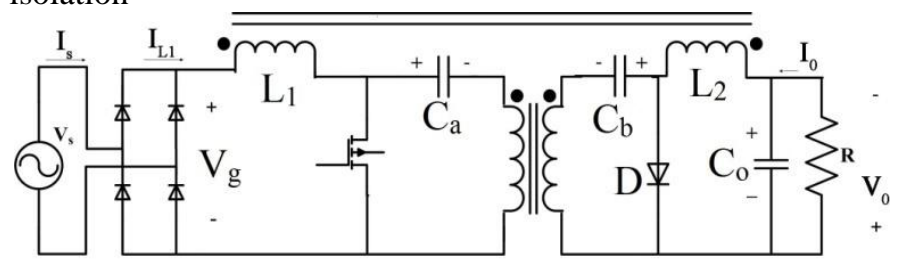

Figure 1: Single Phase CUK Rectifier Module

\section{POWER FACTOR CORRECTION}

Most of the switch mode power supplies draw non sinusoidal current. When the current is not sinusoidal and the voltage is sinusoidal the power factor consist of two factors

a. The displacement factor related to phase angle

b. Distortion factor related to wave shape

$$
\text { Power Factor }=\frac{I_{\text {rms }(1)}}{I_{\text {rms }}} \operatorname{Cos} \theta
$$

$\mathrm{I}_{\mathrm{rms}(1)}$ - RMS value of Fundamental component of current

$\mathrm{I}_{\mathrm{rms}}-\mathrm{RMS}$ value of current

The measure of line distortion usually used in total harmonic distortion (THD), which is a measure of the harmonic content of a waveform. THD is given by

$$
\mathrm{THD}=\sqrt{\frac{\sum_{\mathrm{n} \neq 1} \mathrm{I}_{\mathrm{n}}^{2}}{\mathrm{I}_{1}^{2}}}
$$

THD and power factor are related since distortion increases the RMS current drawn from the line. It can be shown that power factor and THD are directly related.

$$
\mathrm{PF}=\sqrt{\frac{1}{1+\mathrm{THD}^{2}}}
$$

So the system performance can be improved by increasing the power factor or reducing the THD [8]. The basic idea behind APFC is to force the line current to follow the waveform of the line voltage.

\section{DESIGN PROCEDURE}

Single Phase CUK Rectifier was designed with the following characteristics:

$\begin{array}{ll}\text { Input voltage, } \mathrm{V}_{\mathrm{s}} & =220 \mathrm{~V} \pm 10 \% \\ \text { Line frequency } & =50 \mathrm{~Hz} \\ \text { Power factor } & \geq 0.95 \\ \text { Load resistance } & =10 \Omega \\ \text { Output dc voltage, } \mathrm{V}_{0} & =-48 \mathrm{~V} \\ \text { The turn ratio between } & \\ \text { Primary and Secondary } \mathrm{nTr} & =0.5\end{array}$

The basic equation of an isolated CUK converter is

$$
\frac{\mathrm{V}_{0}}{\mathrm{~V}_{\mathrm{g}}}=\frac{\mathrm{nTr} \mathrm{d}}{(1-\mathrm{d})}
$$

To operate in CCM,

The dc voltage conversion ratio

$$
\mathrm{m} \theta=\mathrm{V}_{0} /\left(\hat{\mathrm{V}}_{\mathrm{g}}|\sin \theta|\right)
$$

The $\mathrm{M}$ ratio is,

$$
\mathrm{M}=\frac{\mathrm{V}_{0}}{\hat{\mathrm{V}}_{\mathrm{g}}}=.1543
$$

2) The conduction parameter of the CUK PFC circuit

$$
K_{a}>\frac{1}{2(\mathrm{M}+\mathrm{n} \operatorname{Tr}|\sin \theta|)}>1.167
$$

Here, $K_{a}$ is chosen to be equal to 2 .

3) An equivalent inductance

$$
\mathrm{L}_{\mathrm{eq}}=\frac{\mathrm{RT}_{\mathrm{Sw}} \mathrm{K}_{\mathrm{a}}}{2}=.3072 \mathrm{mH}
$$

By choosing the input inductor current with $30 \%$ current ripple, $\Delta \mathrm{i}_{\mathrm{L} 1}=0.482 \mathrm{~A}$. The design of $\mathrm{L}_{1}$ and $\mathrm{L}_{2}$ is made using the desired ripple value of the input current. When the nominal duty cycle $\mathrm{d}=0.235$, the input-side inductor $L_{1}$ is chosen based on the specified maximum current ripple [1] [7].

$$
\mathrm{L}_{1}=\frac{\mathrm{V}_{\mathrm{g}} \mathrm{dT}_{\mathrm{sW}}}{\Delta \mathrm{i}_{\mathrm{L} 1}}=5.068 \mathrm{mH}
$$

The measured inductance of the designed input inductor is $5 \mathrm{mH}$ at $30 \mathrm{kHz}$.

For the Coupled Inductor extension of CUK converter, the output-side inductor $L_{2}$ is then selected using the normalized plot of amplitude of current ripples input and output inductor current as a function of turns ratio [13].

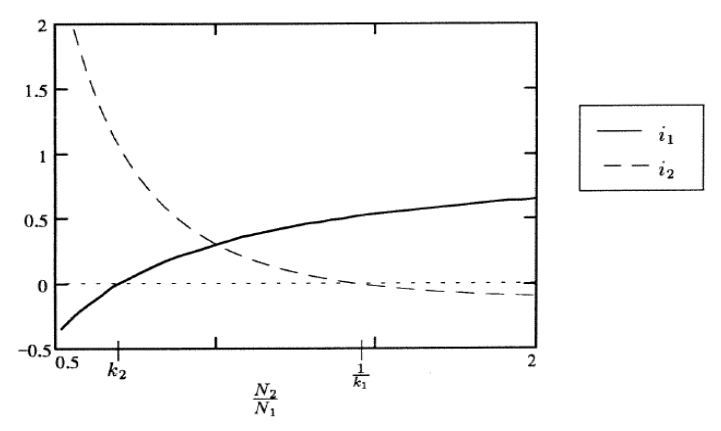

Figure 2: Normalized Plot of Amplitude of Current Ripples $i_{1}$ and $i_{2}$ as Function of Turns Ratio

Figure 2 shows the normalized value of current ripples as a function of turns ratio. Notice zero ripple current can obtained in the secondary when $\mathrm{k}_{1}=\mathrm{N}_{1} / \mathrm{N}_{2}$ and similarly zero ripple in primary current if $\mathrm{k}_{2}=\mathrm{N}_{2} / \mathrm{N}_{1}$, where $\mathrm{N}_{1} \& \mathrm{~N}_{2}$ number of turns in primary and secondary of Coupled Inductor \& $\mathrm{k}$ is the 
coupling coefficient. By selecting suitable values for $\mathrm{N}_{1} \& \mathrm{~N}_{2}$ ripple current elimination is possible [4][12].

From Figure 2 the value of inductor for minimum ripple in both primary and secondary can be calculated.

Select $n=N_{2} / N_{1}=0.8666$, for maximum ripple reduction in the primary and secondary side.

$$
\begin{aligned}
& \mathrm{L}_{1}=5 \mathrm{mH} \\
& \mathrm{L}_{2}=\mathrm{n}^{2} \mathrm{~L}_{1}=3.698 \mathrm{mH}
\end{aligned}
$$

The design of the intermediate capacitor $\mathrm{C}_{\mathrm{a}}$ considering a resonant frequency of $3.5 \mathrm{kHz}$, which is a good initial approximation for $\mathrm{C}_{\mathrm{a}}$, is given by

$$
\mathrm{C}_{\mathrm{a}}=\frac{1}{\omega_{\mathrm{r}}^{2}\left(\mathrm{~L}_{1}-\mathrm{L}_{2}\right)}=.55 \mu \mathrm{F}
$$

Let $\mathrm{C}_{\mathrm{a}}=0.68 \mu \mathrm{F}\left(\mathrm{C}_{\mathrm{a}}=\mathrm{C}_{\mathrm{b}}\right)$. The output dc capacitance $\mathrm{C}_{0}$ is determined according to the hold-up time $\Delta$ th . By choosing $\Delta \mathrm{th} \geq 2 \mathrm{~ms}$,

$$
\mathrm{C}_{0 \min }=\frac{2 \mathrm{P}_{0} \Delta_{\text {th }}}{\mathrm{V}_{0}^{2}-\mathrm{V}_{0}^{2} \text { min }}=10683 \mu \mathrm{F}
$$

Minimum capacitor value $\left(C_{\mathrm{o}} \mathrm{min}\right)$ must be derated for capacitor tolerance $\left(\Delta \mathrm{C}_{\text {tol }}\right), 20 \%$ in this case, in order to guarantee that minimum capacitance requirement is satisfied, thus assuring minimum hold-up time.

$$
\mathrm{C}_{0}=\frac{\mathrm{C}_{0 \text { min }}}{1-\Delta \mathrm{C}_{\text {tol }}}=13,353 \mu \mathrm{F}
$$

Let $\mathrm{C}_{0}=13,600 \mu \mathrm{F}$ for given $\mathrm{V}_{\mathrm{o}}$ and $\mathrm{V}_{\mathrm{o} \text {,min }}$, the larger the power $\mathrm{P}_{0}$ and or the longer the hold-up time $\Delta$ th, the larger the energy-storage capacitor $\mathrm{C}_{0}$ that needs to be used.

\section{CONTROL SCHEME}

Figure 3 shows control structure and detailed control block and the control scheme based on power balance control [1].

For the control block operations following quantities are to be sensed

\section{Supply voltage $\mathrm{V}_{\mathrm{s}}$}

\section{Inductor current $\mathrm{I}_{\mathrm{L} 1}$ \\ 3. Output voltage $\mathrm{V}_{0}$ and current and $\mathrm{I}_{0}$}

Measured output voltage is compared with the reference voltage and the error is given to the PI controller whose output $\left(\mathrm{I}_{\mathrm{vr}}\right)$ is added with peak value of input inductor current. Using the sensed values of $V_{0}$ and $I_{0}$, the peak value for input inductor current is calculated based on power balance concept as follows.

$$
\begin{aligned}
& \mathrm{V}_{\mathrm{rms}} * \mathrm{I}_{\mathrm{rms}}=\mathrm{V}_{0} * \mathrm{I}_{0} \\
& \mathrm{I}_{\mathrm{m}}=\left(1.414 * \mathrm{~V}_{0} * \mathrm{I}_{0}\right) / \mathrm{V}_{\mathrm{rms}} \\
& \mathrm{I}_{\text {Lref } \mathrm{i}}=\mathrm{I}_{\mathrm{m}}+\mathrm{I}_{\mathrm{vr}}
\end{aligned}
$$

$I_{\text {Lrefi }}$ is the reference value for the peak value of input inductor current. $I_{L 1}$ is the input inductor current. $I_{v r}$ is the correcting signal from PI controller. The inductor reference current is then obtained by multiplying it with sine wave template, ie.

$$
\mathrm{I}_{\text {Lref }}=\mathrm{I}_{\text {Lrefi }} *|\sin \omega \mathrm{t}|
$$

After obtaining the actual current and reference current switching signals can be generated by using peak current control. Main advantages of peak current control is constant switching frequency and no need of current error amplifier and its compensation network [6][15].

The advantages of the proposed system are: high power factor, modularity, simple control strategy, and design. The output voltage is regulated [1].

\section{Simulation AND Result}

This section discusses the simulation of proposed high quality single phase CUK rectifier and normal AC - DC rectifier and its results.

Figure 4 shows the circuit diagram of AC-DC rectifier \& Fig. 5(a) \& 5(b) shows its corresponding input current and input voltage waveform respectively. In this case the input current THD is very high, this can be reduced by replacing this rectifier with a high quality CUK rectifier module.

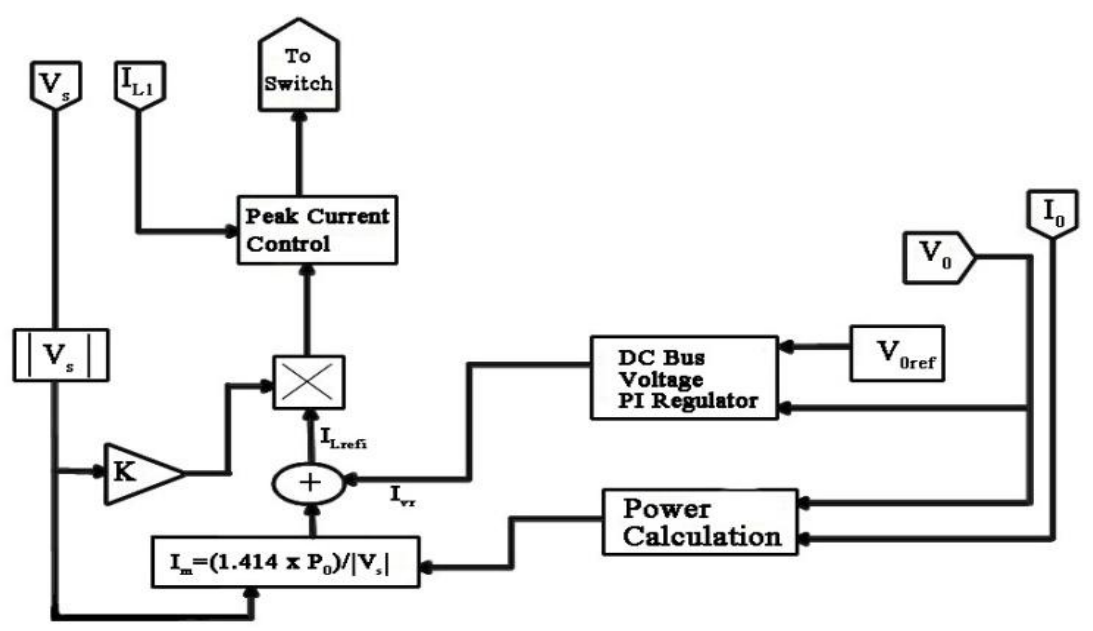

Figure 3: Control Structure and Detailed Control Block 


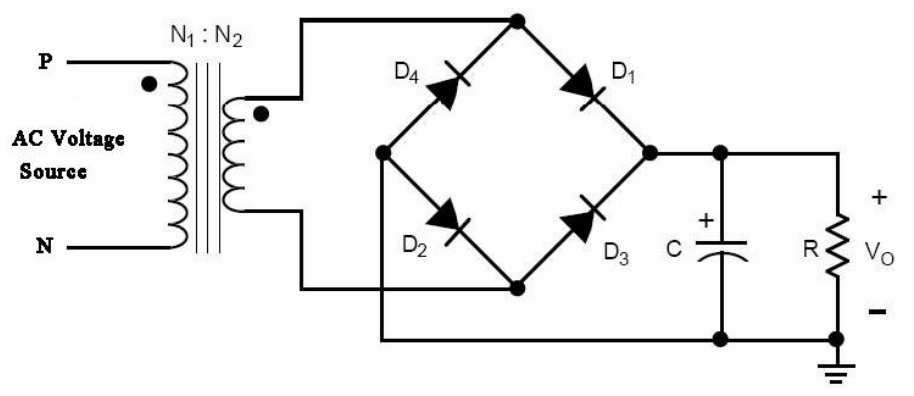

Figure 4: AC - DC Rectifier Circuit

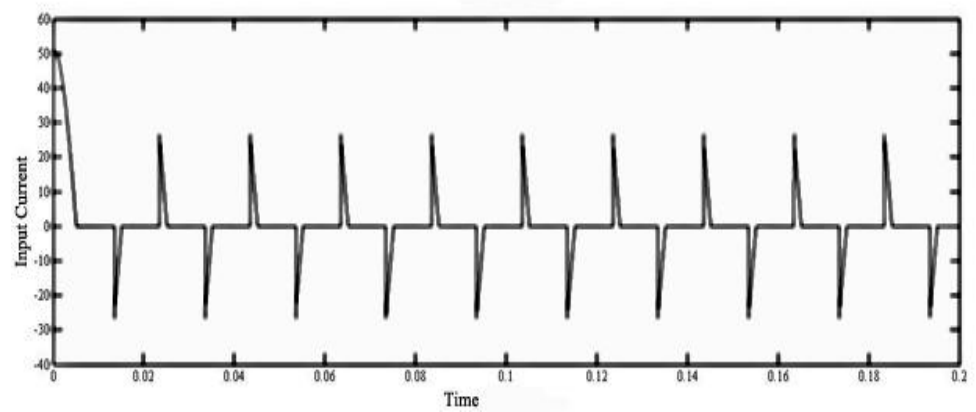

Figure 5(a): Input Current Vs Time

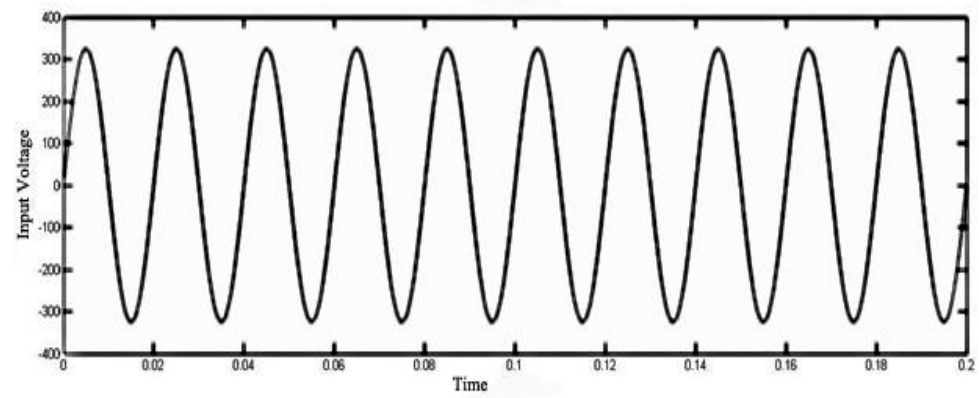

Figure 5(b): Input Voltage Vs Time

The proposed system configuration shown in figure 1 is simulated using SIMULINK program. A rated operation of $250 \mathrm{~W}$ output power and $-48 \mathrm{~V}$ of dc output voltage with $220 \mathrm{~V}$ of ac line to neutral voltage in rms are assumed. Table 1 shows design values for simulation.
Table 1: Specification and Parameters of a Single Phase CUK Rectifier Module

\begin{tabular}{|l|l|}
\hline \multicolumn{1}{|c|}{ Characteristic } & \multicolumn{1}{c|}{ Power Modules } \\
\hline $\begin{array}{l}\text { Input phase } \\
\text { voltage }\end{array}$ & $220 \mathrm{~V}$ \\
\hline Input frequency & $50 \mathrm{~Hz}$ \\
\hline Output Power & $250 \mathrm{~W}$ \\
\hline $\begin{array}{l}\text { Switching } \\
\text { frequency }\end{array}$ & $30 \mathrm{kHz}$ \\
\hline Output Voltage & $-48 \mathrm{~V}$ \\
\hline $\mathrm{L}_{1}$ & $5.068 \mathrm{mH}$ \\
\hline $\mathrm{L}_{2}$ & $3.67 \mathrm{mH}$ \\
\hline $\mathrm{C}_{\mathrm{a}}=\mathrm{C}_{\mathrm{b}}$ & $0.68 \mu \mathrm{F}$ \\
\hline $\mathrm{C}_{0}$ & $13600 \mu \mathrm{F}$ \\
\hline
\end{tabular}




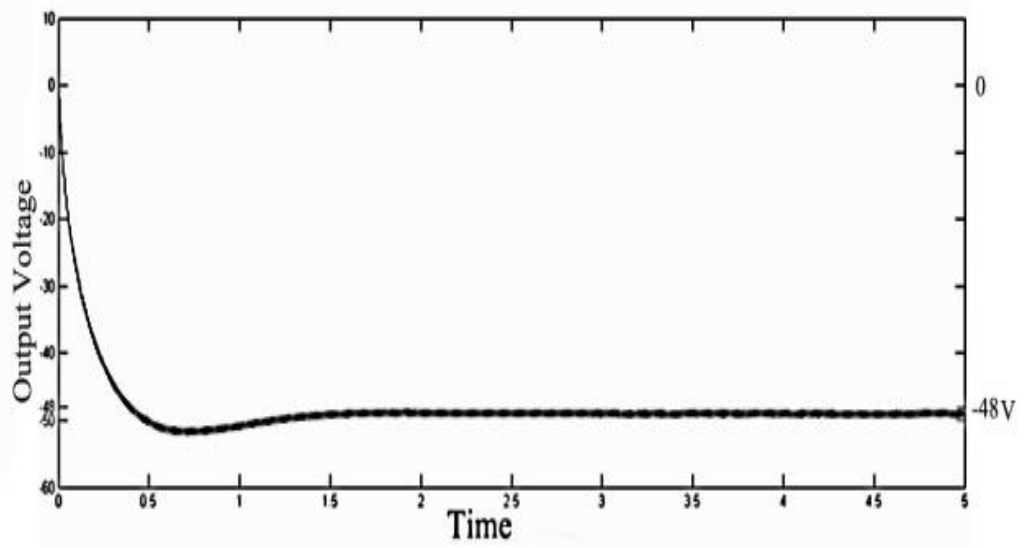

Figure 6(a): Regulated output DC voltage

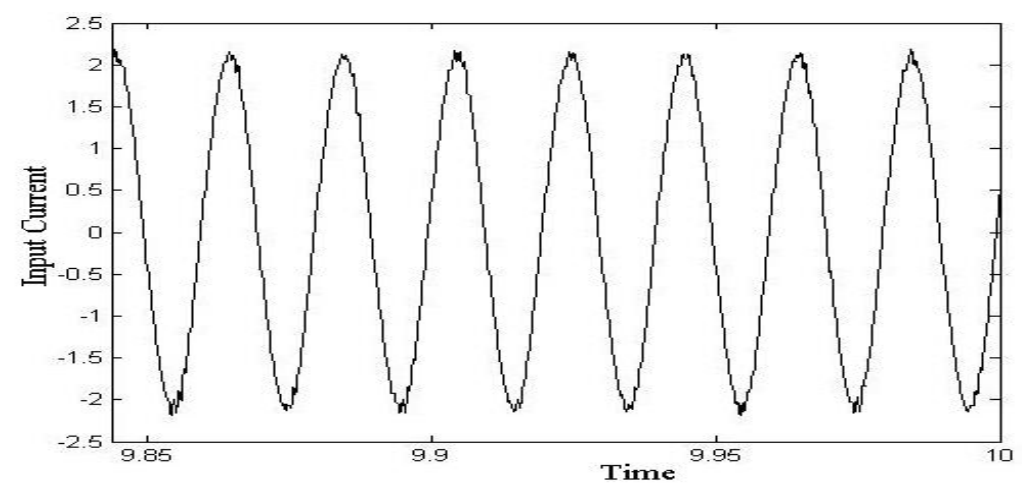

Figure 6(b): Input Current

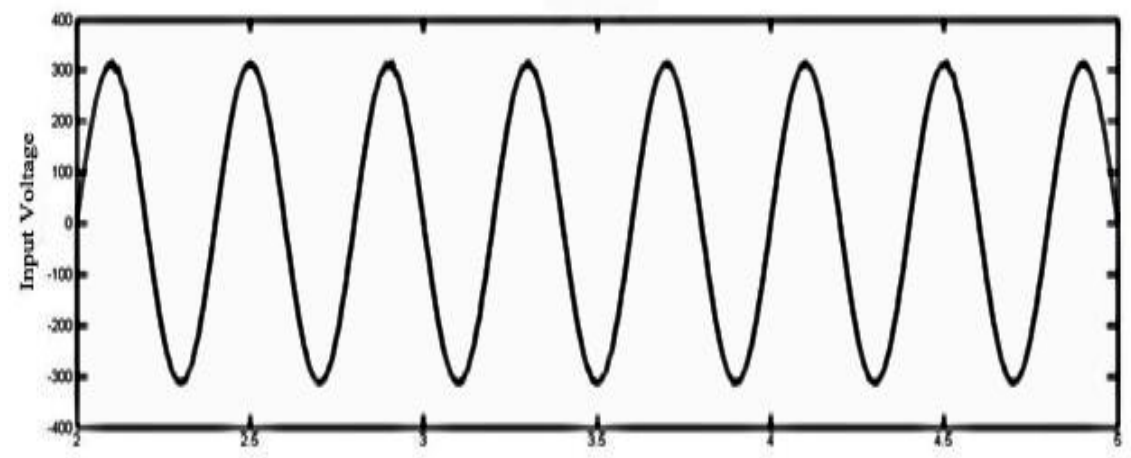

Figure 6(c): Input Voltage 


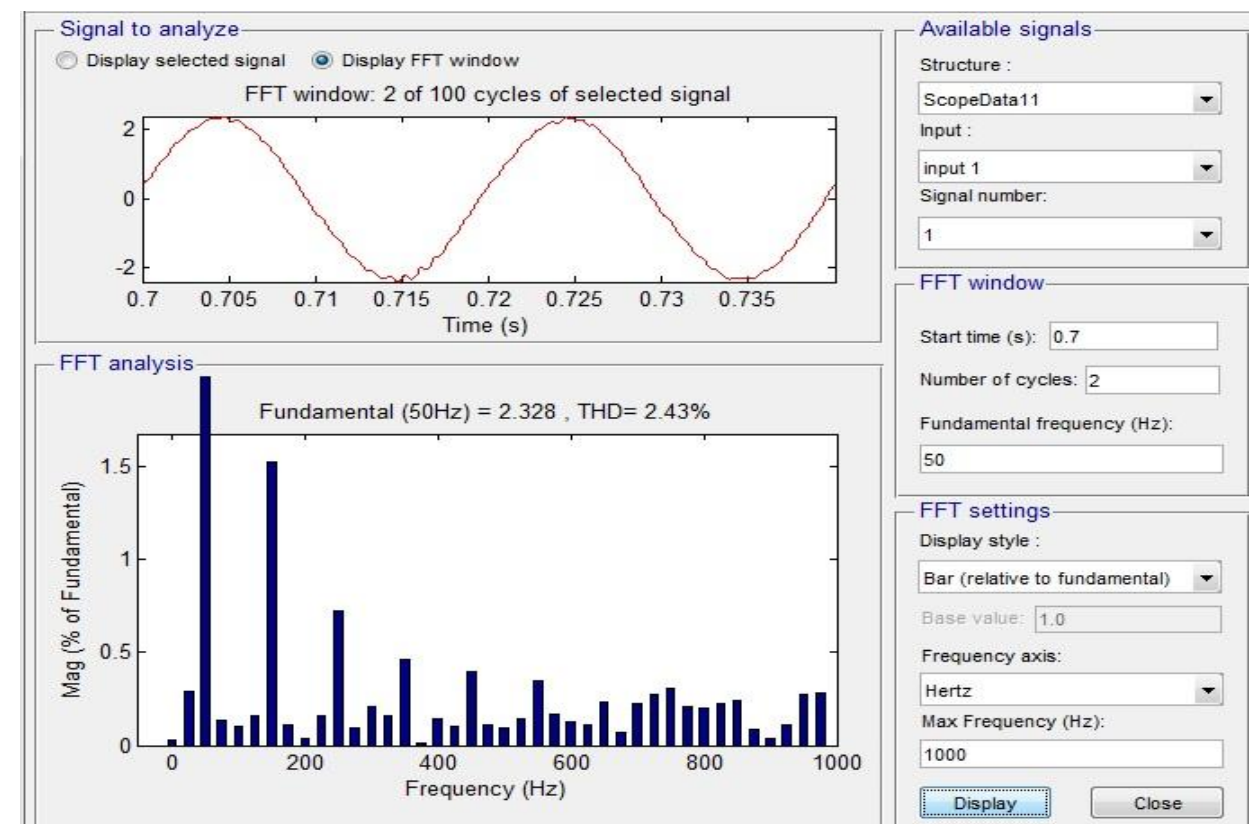

Figure 6(d): FFT Analysis of Input Current

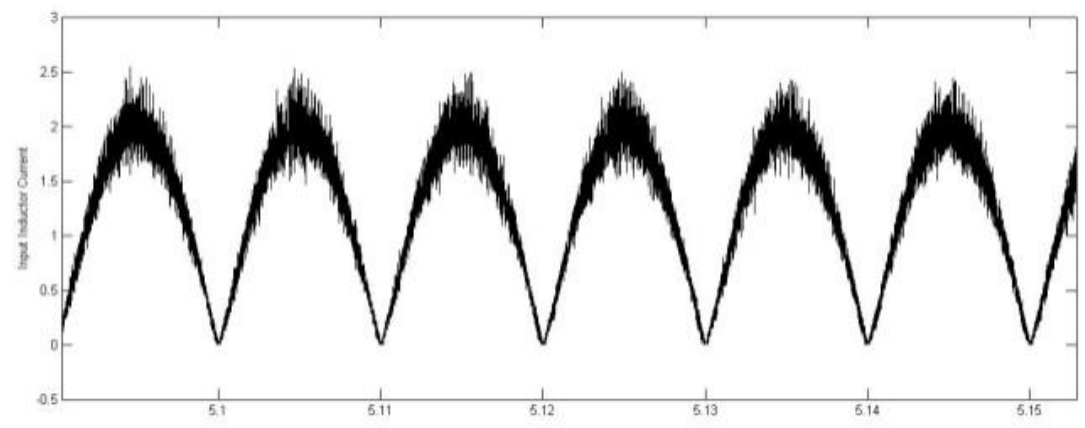

Figure 6(e): Input Inductor Current

Figure 6(a) shows the regulated dc output voltage. Figure 6(b) and figure 6(c) shows the input current and input voltage waveform respectively, graph clearly shows that input current is nearly sinusoidal and also the figure 6(d) shows the FFT analysis of input current.

Figure 6(e) shows the input inductor current waveform. The input current THD is only $2.43 \%$, it meets international standards for harmonic regulation such as IEC 61000-3-2. International regulation is that THD should be less than 5\%, which is satisfied in the simulation results.

\section{HARDWARE EXPERIMENTS}

$\begin{array}{ll}\text { Input Voltage } & : 10-15 \mathrm{~V} \\ \text { Load Resistance } & : 20-200 \mathrm{Ohm}, 2.5 \mathrm{~A} \\ \text { Load Voltage } & :-7 \mathrm{~V}\end{array}$

A prototype of single phase ac-dc converter has been built with components value same as shown Table 1, instead of $-48 \mathrm{~V}$ output voltage the prototype is tested for only $-7 \mathrm{~V}$ output voltage. The main objective is to improve the input current power factor and a regulated output voltage. Control circuitry is implemented using analog circuits. 

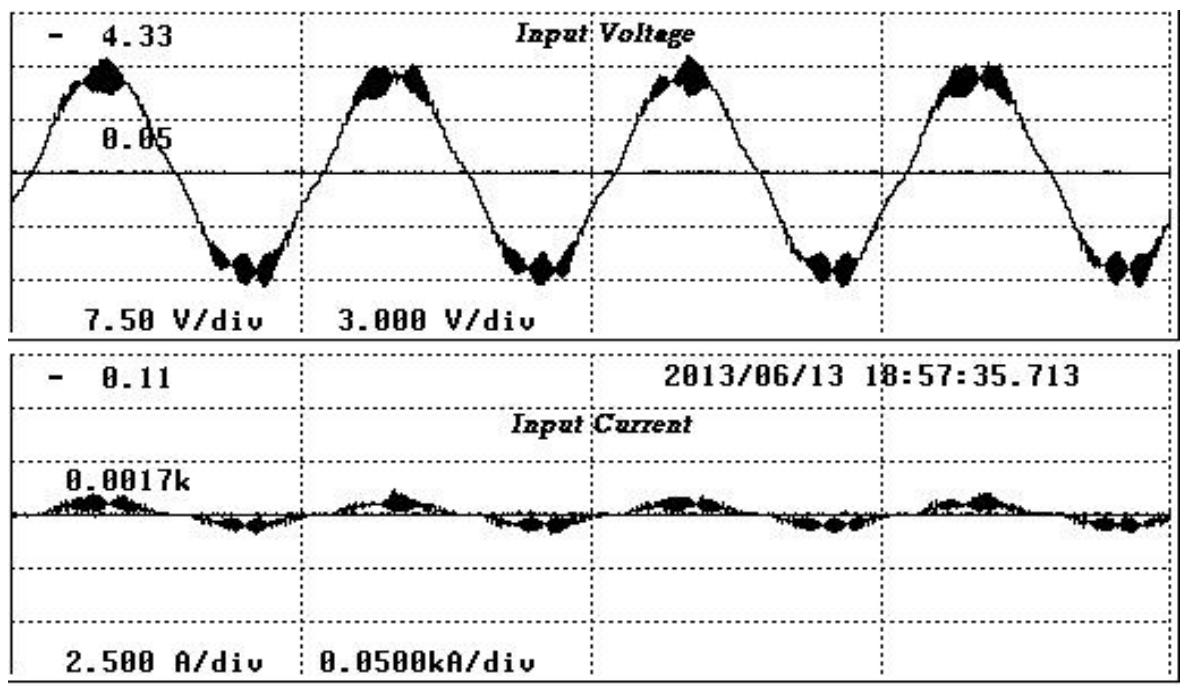

Figure 7(a): Hardware Results of Input Voltage and Input Phase Current

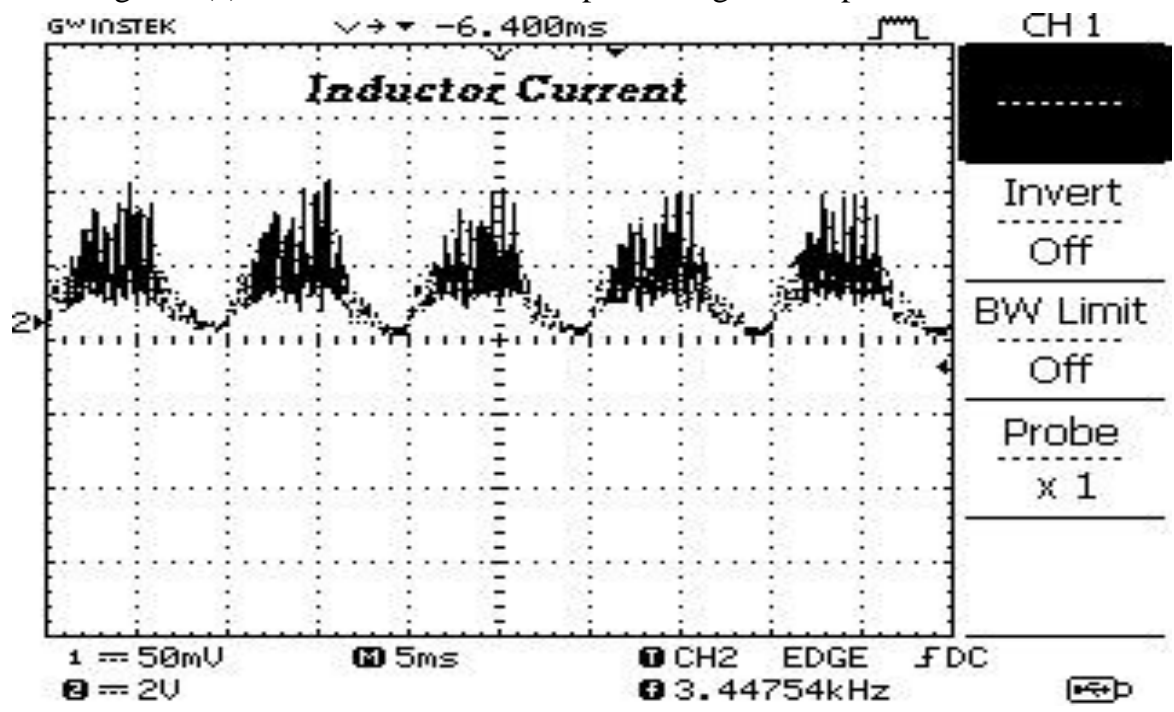

Figure 7(b): Hardware Results of Input Inductor Current

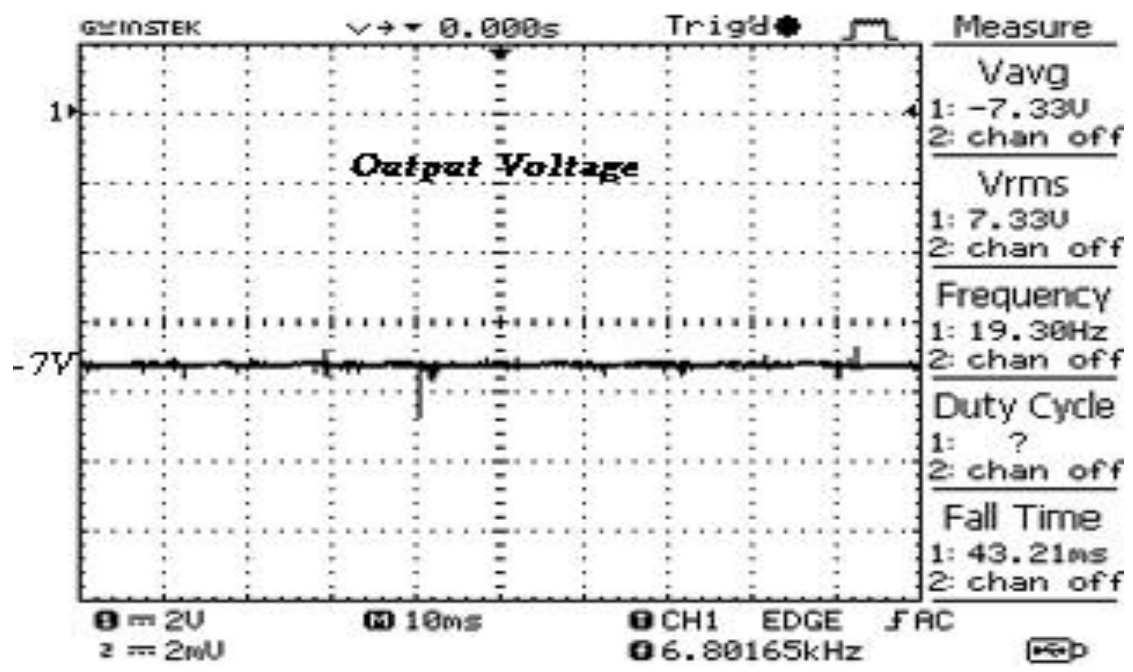

Figure 7(c): Hardware Results of Output Voltage 


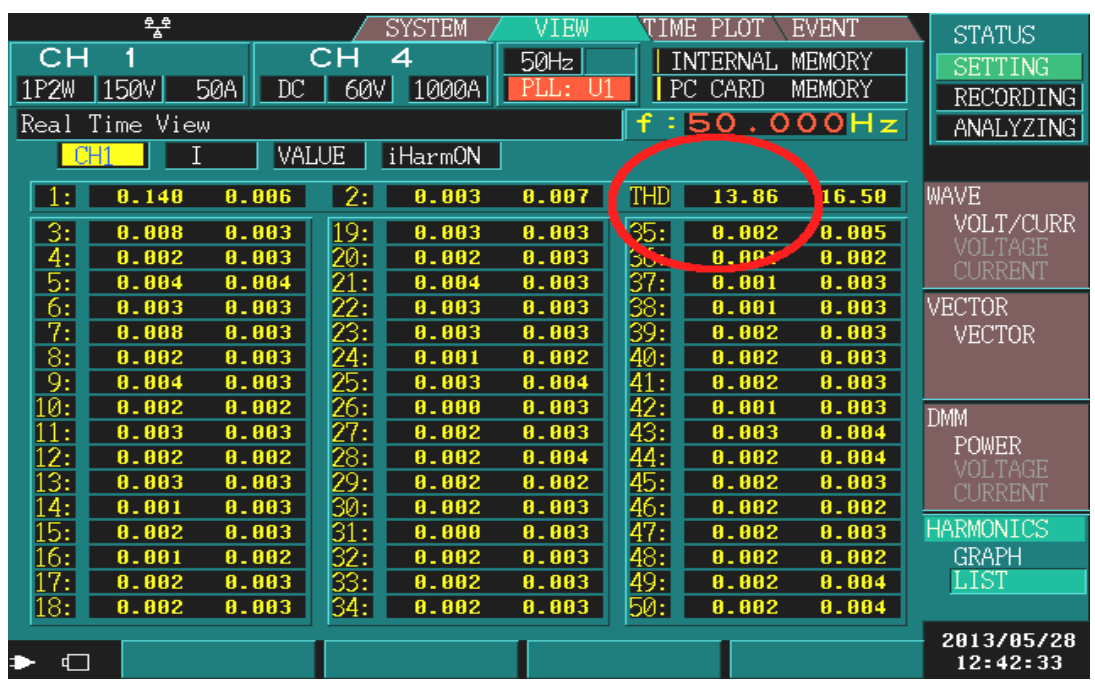

Figure 7(d): Hardware Results of Input Current THD

Figure 7(a), 7(b), 7(c) and 7(d) shows the hardware experimental results input voltage and input current, inductor current, output voltage and input current THD respectively. As we can see that input current is sinusoidal in shape. Also total current THD is found to be $13.8 \%$. Compared to THD obtained during simulation $(2.43 \%)$ hardware results show increased THD. There are many reasons for this irregularity. In the simulation everything was assumed to be ideal. For example the supply voltage is assumed to be purely sinusoidal in shape, which is not the practical case. Since the same waveform is used as the unit template it will affect the performance of the system. Other possible reasons are the non-linearitys which may be present in the control circuit.

Most of the PFC converter uses boost converter, Table 2 shows comparison of proposed converter with most commonly used boost PFC converter.

Table 2: Comparison of Proposed Converter with Single Phase PFC Boost Converter

\begin{tabular}{|c|c|c|}
\hline Characteristics & $\begin{array}{l}\text { Single Phase CUK } \\
\text { converter }\end{array}$ & $\begin{array}{l}\text { Single Phase Boost } \\
\text { PFC Converter }\end{array}$ \\
\hline $\begin{array}{l}\text { Efficiency of the } \\
\text { converter }\end{array}$ & Good & Fair \\
\hline $\begin{array}{l}\text { Range of Output } \\
\text { Voltage }\end{array}$ & $\begin{array}{l}\text { Tight output voltage } \\
\text { regulation, Both } \\
\text { buck and boost } \\
\text { operation is } \\
\text { possible. }\end{array}$ & $\begin{array}{l}\text { Output voltage is } \\
\text { always greater than } \\
\text { input voltage; } \\
\text { second stage } \\
\text { converter is } \\
\text { required for step } \\
\text { down the output } \\
\text { voltage to its } \\
\text { required level. }\end{array}$ \\
\hline $\begin{array}{l}\text { Quality of Input } \\
\text { Current }\end{array}$ & $\begin{array}{l}\text { Inductor coupling } \\
\text { reduces the current } \\
\text { ripples. So input } \\
\text { current quality is } \\
\text { excellent. }\end{array}$ & $\begin{array}{l}\text { Current quality is } \\
\text { good. }\end{array}$ \\
\hline Output Current & $\begin{array}{l}\text { Small amount of } \\
\text { ripples are present. }\end{array}$ & Pulsed \\
\hline $\begin{array}{l}\text { Complexity of control } \\
\text { circuitry }\end{array}$ & $\begin{array}{l}\text { Easily implement } \\
\text { using analog or } \\
\text { digital circuits. }\end{array}$ & $\begin{array}{l}\text { Easily implement } \\
\text { using analog or } \\
\text { digital circuits. }\end{array}$ \\
\hline Isolation & Easy to add & Difficult \\
\hline
\end{tabular}

\begin{tabular}{|l|l|l|}
\hline & $\begin{array}{l}\text { isolation } \\
\text { transformer }\end{array}$ & \\
\hline Magnetic Volume & Large & Small \\
\hline Application & $\begin{array}{l}\text { Medium power } \\
\text { application, Low or } \\
\text { High voltage }\end{array}$ & $\begin{array}{l}\text { Medium power } \\
\text { application, High } \\
\text { voltage }\end{array}$ \\
\hline
\end{tabular}

\section{CONCLUSION AND FutURE SCOPE}

A single phase high quality CUK rectifier module with active Power Factor Correction simulated using Matlab/Simulink software. This system reduces the number of conversion stages and provides proper isolation. The Coupled Inductor reduces input and output current ripples, reduces the core cost, EMI filtering components and constant switching frequency can be achieved by peak current control. The results obtained are regulated $-48 \mathrm{~V}$ dc voltage with THD $2.43 \%$ and power factor of 0.98 which satisfies international harmonic regulation standards such IEC 61000-3-2. Hardware results a single phase CUK rectifier module provides a regulated output voltage of $-7 \mathrm{~V}$ with input current THD $13.8 \%$ this increase in THD may be due to the non-linearity's present in the control circuit and THD of the input line voltage, which is observed as around $8 \%$. By comparing ordinary rectifier with cuk rectifier module, present system gives low THD value with improved input power factor.

Results show that the controller is working properly with tight output voltage regulation and input current wave shaping. So input current THD can be reduced by incorporating the power balance control in dc to dc converter and thereby it achieves better input power factor.

- In the present implementation only the inductors are coupled. But it is possible to integrate inductors and isolation transformer on a single magnetic core so that ripple current can be further reduced.

- In the implemented hardware the supply voltage waveform is used as the unit template current reference waveform. But distortions in the voltage waveform will affect the performance of the system. In order to avoid this, a reference line-to-neutral 
voltage may be generated by mean of using a phase locked loop (PLL) system.

\section{REFERENCES}

[1] U. Kamnarn and V. Chunkag, "Analysis and Design of a Modular Three Phase Ac To Dc Converter Using Cuk Rectifier Module With Nearly Unity Power Factor And Fast Dynamic Response", IEEE transactions on power electronics, Vol. 24, No.8, Pp. 2000-2012, August 2009.

[2] S. Cuk and R.D. Middlebrook, "Advances in Switched Mode Power Conversion Part1", IEEE transactions in industrial electronics, Vol.ie 30, No. 1, Pp. 10-19, February 1983.

[3] S. Cuk and R.D. Middlebrook, "Advances in Switched Mode Power Conversion Part11" IEEE transactions in industrial electronics, Vol.ie 30, No. 1, FEBRUARY 1983

[4] S. Cuk, "A New Zero-Ripple Switching DC-DC Converter and Integrated Magnetics," in Proc. IEEE Power Elec. Specialists Conf., May 1980

[5] Bhim Singh and Ganesh Dutt Chaturvedi, "Analysis, Design, Modeling, Simulation and Development of Single-Switch AC-DC Converters for Power Factor and Efficiency Improvement" Journal of Power Electronics, Vol. 8, No.1, January 2008.

[6] L. Rossetto, G. Spiazzi and P. Tenti, "Control Techniques for Power Factor Correction Converters".

[7] D.S.L. Simonetti, J. Sebastian, F.S. dos Reis, and J. Uceda, "Design criteria for SEPIC and CUK converters as power factor preregulators in discontinuous conduction mode," in Proc. IEEE PEMC Conf., Pp. 283288, 1992.

[8] J. Sebastian, J. Uceda, A. Cobos, J. Arau and F. Aldana" Improving Power Factor Correction in Distributed Power Supply Systems Using PWM And ZCS-Or Sepic Topologies" IEEE Trans. Ind. Electron Nov1991

[9] M. Brkovic and S. Cuk, "Input Current Shaper Using CUK Converter," inProc. IEEE INTELEC Conf., Pp. 532-539, 1992.

[10] B.N. Singh, A. Chandra, K. Al-Haddad, A. Pandey, D.P. Kothari, "A review of three-phase improved power quality AC-DC converters," IEEE Trans. Ind. Electron., Vol.51, No. 3, Pp. 641 - 660, June 2004.

[11] Bhim Singh and Ganesh Dutt Chaturvedi., "Modelling Simulation and Development of Isolated Cuk AC-DC Cuk Converter in DCM and CCM Operation" IETE journal of research, Vol. 54, No. 6, Nov 2008.

[12] S. Cuk, "DC-to-DC Switching Converter with Zero Input \& Output Ripple and Integrated Magnetics Circuits," U.S. Patent 4257 087, Mar. 17, 1981.

[13] P.W. Lee, Y.S. Lee, D.K.W. Cheng, and X.C. Liu, "Steady-state analysis of an interleaved boost converter with coupled inductors," IEEE Trans. Ind. Electron., Vol. 47, Pp. 787-795, Aug. 2000.

[14] V. Vorperian, R.B. Ridley, "A Simple Scheme for Unity Power-Factor Rectification for High Frequency AC Buses". IEEE Transactions on Power Electronics, Vo1.5, w.1. Pp. 77-87, January, 1990.

[15] J. P. Gegner and C.Q. Lee, "Linear peak current mode control: A simple active power factor correction control technique," in Proc. IEEE PESC, Pp. 196-202, 1996.

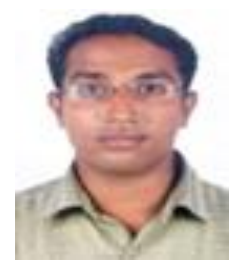

Jidhun K Murali was born in Ernakulam, Kerala, India in 1988. He received B. Tech degree in Electrical and Electronics Engineering from Federal Institute of Science and Technology, Angamaly, Kerala, India, in 2009, the M.Tech degree in Power and Energy Engineering from Amrita School of Engineering, Amrita Vishwa Vidyapeetham, Amritapuri, Kerala, India in 2013. His research interest includes power electronic converters, Power Factor Correction and power system harmonics. 